\title{
New Zealand Music in the Popular Imagination 1988-2010: Revisiting a Moment for 'Our Music'.
}

Matt Mollgaard

Keywords: \# New Zealand music \# national popular music \# New Zealand on Air \#music culture

From the late 1980s until around 2010 a new type of national conversation arose around music created in Aotearoa/ New Zealand. This conversation was played out in popular literature, public forums, academic research and ultimately in government policy outputs. This period of energy and enthusiasm for claiming a unique musical heritage and in developing the cultural, social and economic potential of this music was brief, but notable. Looking back, we can clean interesting insights into a period of real enthusiasm for New Zealand music as an important signifier of what it meant to be 'from New Zealand' through books about New Zealand music aimed at mainstream audiences. This interest in discussing New Zealand music in new ways was also reflected in the academy, with attempts to deconstruct the popularity of New Zealand music and government involvement in it being published around the same time. This article is by no means an exhaustive history of this period in New Zealand music literature, but a review of key books and the common themes that strung them together in what represents not a canon, but a moment in New Zealand music that captured the popular imagination and was celebrated in print as well as discussed in broader academic forums too. This moment can be critiqued as gendered dominated by male writers and therefore male perspectives, 
but that is not the purpose of this article. This flurry of publishing is cast here as a reaction to popular culture that was very much of its time and the wider contexts of New Zealand's socio-political culture during that period. It is argued that ultimately, this rash of books about New Zealand music reflected an energy around trying to connect New Zealand music to the wider work of identifying and celebrating a maturing and definitive understanding of what it meant to be from New Zealand. This fed a wider interest in New Zealand music as significant inside the academy and also within government agencies charged with supporting cultural work.

\section{SITUATING POPULAR MUSIC IN THE NATIONAL IMAGINATION}

Landmark popular studies of New Zealand music such as John Dix's Stranded in Paradise, Bryan Staff and Sheran Ashley's For the Record and David Eggleton's Learning to Fly celebrated a sense of cultural uniqueness driven by geographic as well as social quirkiness that supposedly created a New Zealand 'sound' that was both stylistically and culturally remarkable and distinctly 'of New Zealand', like no other music was - or could be. Thematic narratives emerged and coalesced into ideas such as 'Noisy Land', a 'Dunedin Sound' and 'Urban Pacific' styles that spoke of a musical place like nowhere else.

Multiple contested discourses emerged during this period that contrasted passion and love for New Zealand music with the competitive market realities of the global media and music industries. This demonstrates difficulties in nurturing 'national' popular music in neo-liberal environments, such as the laissez-faire environment of post-deregulation New Zealand. Love, passion and care for that culture can also become conduits for corporate capture of the unique movements and moments encapsulated in the idea of 'our music'. This article explores the narratives of New Zealand music during this period and how they attempted to describe and engage with New Zealand music as culture and as a signifier of national independence, pride and achievement.

\section{NATION MUSIC AS CONTESTED CULTURE}

Notions of 'national' musical culture are complex, as they must define what 'national' is as a starting point. This is especially complex in the face of globalization, trans-national cultural moments and movements and the ongoing 'shrinkage' of the world due to rapidly spreading worldwide communication networks. What 'national' is has become defined by what it is not, rather than by a geographical place, a set of common values and norms and a common culture, in the face of an intrusive international culture which is understood as globalization. New Zealand faces the same pressures and problems as other open economies and internationally-connected nation states with relatively open borders - both physical and cultural - in identifying 'national' music as distinct from anything else.

Motti Regev examined the global music industries as notions of globalization began to emerge in public discourse during the late 1980 s and early $1990 \mathrm{~s}$. For Regev, the global music industry was creating audiences of "reflexive communities focusing their sense of identity and difference around particular mixes of cultural materials". ${ }^{1}$ Further to this, Regev argued for a global rock music aesthetic that had created "a common reference point for musicians and listeners around the world" - a construction understood by audiences as "modern-universal, and local or national". 2 Regev unpacked a 'cultural logic' of globalization in that "fields of production expand into webs of local and global positions", meaning that "local styles of music become part of one history, variations on one cultural form - without necessarily losing a sense of difference". ${ }^{3}$

David Hendy notably examined the interaction of the global music industry with local music and radio, stating that "the global and local are entwined by radio" as audiences are now situated in a global culture as "communities of interest linked around the globe", rather than finding commonalities in a geographical place. ${ }^{4}$ Hybridity becomes possible and even the norm in this new globalized environment, as the local and transnational entwine in Hendy's formulation.

lan Biddle and Vanessa Knights interrogated a trend in popular music studies to study the influence of notions of place on local and national music, calling these studies of style, identification, ethnicity, genre and location "cartographies of music". ${ }^{5}$ This "tendency to foreground micro-communities and their local engagements" is seen as usurping the dominance of national music narratives as streets, towns, cities and areas are connected to particular styles and genres 
in these studies. The "idealization of place", while "methodologically extraordinarily productive", can result in "romanticization of the local as inherently 'subversive', 'oppositional' and 'authentic'", while music that is not somehow grounded in locality becomes inauthentic and artificial. ${ }^{6}$ Biddle and Knights argue for "re-encountering the national" to "uncover" the national as a "mediator in the global/local syllogism". Critical to this work is:

The large and complex history of the encounter between popular music, nations and nationalisms [that reveals] an extraordinary tension between the centralized cultural policies of nation-states and the 'local' or more distributed practices of popular musicians.

They conclude that popular music offers a way to "open out the national", beyond a place with a located ideology, but also as a "territory that has symbolic force beyond its parochial-political needs". 9 There is now an obvious site of contestation to grapple with as the fluid and unstable nature of the nation-state encountering the nationalistic, the local and the global presents new ways to understand the production and reception of music as "demonstrating the nationa as a liminal or interstitial space" that situates the mutuality of local and global exchanges. ${ }^{10}$ Ultimately then, popular music can be heard as both from and from beyond the nation it originated from - resonating with the place it is created in and inflected with global musical cultures. This does not 'remove' the national from the music created in a place but does allow for a more nuanced understanding of what 'national' music is. This was reflected in writing about New Zealand music at the time, although to varying degrees and with sometimes with mixed messages about the efficacy of arguing for a unique musical heritage.

\section{NEW ZEALAND MUSIC 'COMES OF AGE'}

Towards the end of the $20^{\text {th }}$ and into the $21^{\text {st }}$ century, there was a rash of publications that were popular histories and critiques of New Zealand music by New Zealanders. Authors such as Chris Bourke, Nick Bollinger, Grant Smithies, Gareth Shute, David Eggleton, John Dix, Bryan Staff and Sheran Ashley produced fine-grain studies of music in New Zealand as popular histories of genres, periods and industry developments.
There were also popular publications that were annotated lists of top music selections from established music critics such as Nick Bollinger and Grant Smithies. These publications are replete with detailed accounts from musicians, industry players and audiences as well as glossy, rarely seen and often spectacular photography. These are very much 'national' narratives, aimed at broad, fan-based, but also, layman audiences and focus on the adaptation of international styles and the influence of locality, distance, spaces and indigenous influences on New Zealand music. These are worth explication here, as they help to situate New Zealand music cultures in broader notions of 'New Zealand-ness'. The books discussed here are not a complete bibliography of all writing about New Zealand music at the time but have been chosen for their popular significance - they can still be found in public library catalogues and they stood out to the author as an interested professional as signifying an important shift in publishing on New Zealand music. The eight books discussed here are therefore symbolic of a wider expansion in the discussion of what New Zealand music meant at the time of publishing - a moment that saw these volumes published between 1988 and 2010

\section{POPULAR NEW ZEALAND MUSIC IN PRINT}

Jon Dix (2005) began this recent revisiting of New Zealand as a place with a unique musical heritage with a detailed and extensive discussion of 'New Zealand rock and roll' from 1955 to 1988 (revised and updated in 2005) in the book Stranded in Paradise. Dix deftly traces the roots of 'modern era' popular New Zealand music from post-war community hall dances and early recordings to a vibrant, diverse and viable local music industry by stringing together the artists that gained national (and sometimes international) acclaim, as well as the various influences of overseas popular culture arriving in New Zealand, the local influences of the indigenous Māori people, the development of a local recording industry and the influence of international and local independent record labels on music made in New Zealand. Dix focuses significantly on commercially successful New Zealand bands and the tone of the book is decidedly celebratory, even deferential throughout, with Dix declaring "I never fancied myself as an historian and I've always thought that there are people better placed than me to take it upon themselves to chronicle the New Zealand music industry"."11 


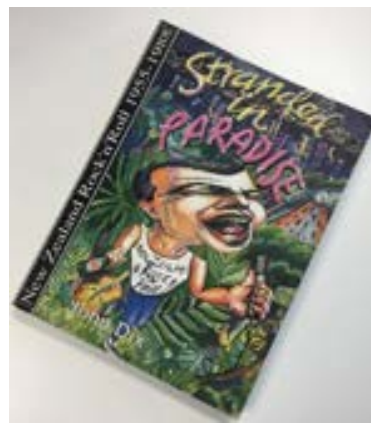

Stranded in Paradise, 1988

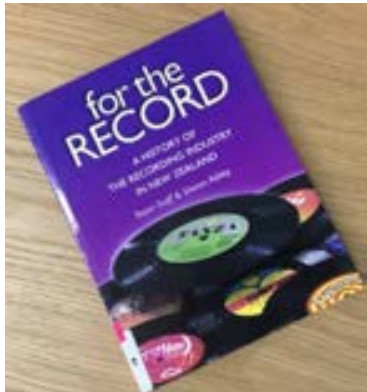

For the Record, 2002

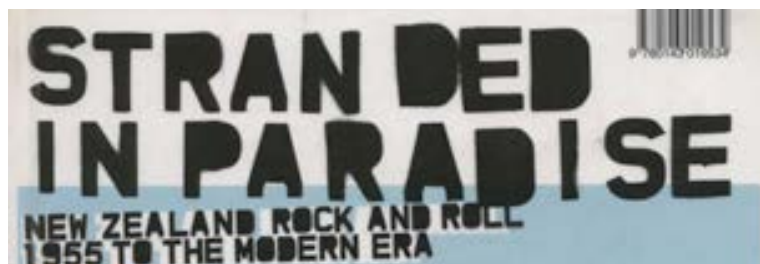

ISE 5 TO THE MO DERN ERA

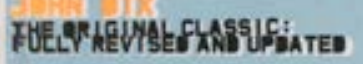

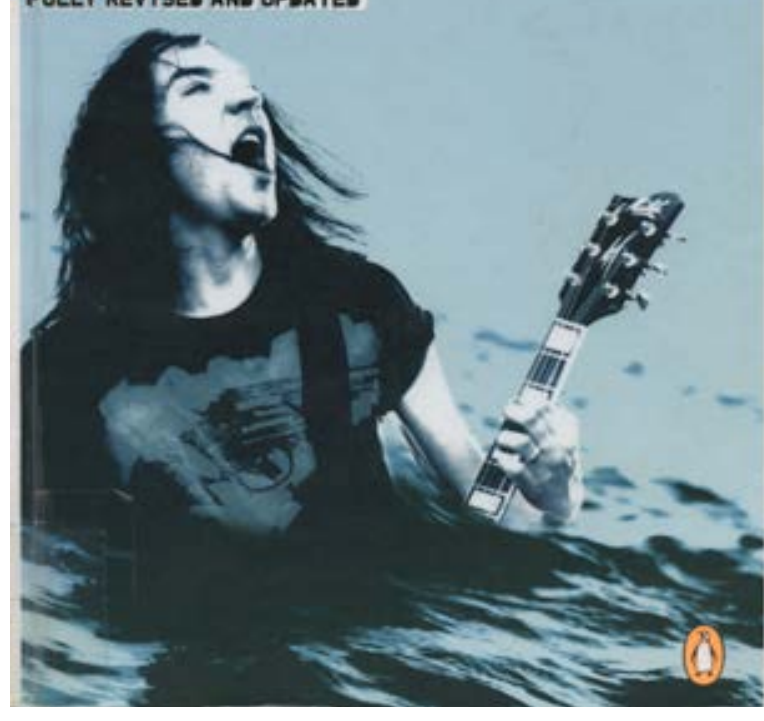

Stranded in Paradise, 2005

Zealand popular music was "plugged directly into the international marketing grid yet remained resolutely indigenous".14 While the title of Stranded in Paradise suggests a music scene removed and remote from international popular music, the realities of the world in New Zealand as well as New Zealand in the world are key features of these volumes. Bryan Staff and Sheran Ashley (2002) also explored notions of a unique New Zealand musical culture in their detailed study of the recording industry in New Zealand from 1940-2000 in the book For the Record: A History of the Recording Industry in New Zealand. Their aim was to "celebrate the New Zealanders which contributed towards our recorded music and consequently our culture when one of our major leisure activities in New Zealand was playing records". ${ }^{15}$ Covering more than 60 years of the history of New Zealand record labels, their artists and the technology that was used by both the recording industry and audiences, Staff and Ashley present New Zealand as a place connected to the contemporary music industry as much as any Western country. As well as detailed histories of all the major (and many minor) recording labels and their various successes, failures and owners, Staff and Ashley explore how musicians combined the international popular music that influenced them with their own influences at home. Staff and Ashley focus on the influence of British and American music for the most part, downplaying the influences of Māori, whose strong and unique tradition of music was also influential on 20th century popular music made in New Zealand. ${ }^{16}$

The foreword to another extensive popular history of New Zealand music poses an interesting question - "Why are we so creative?"17 David Eggleton's 2003 attempt to construct a coherent narrative about 50 years of New Zealand rock music begins with one doyen of New Zealand music, Martin Phillips, positing that "ancestors who escaped various forms of tyranny ... had fire in their hearts, and that spark still survives as a fearsome independence and creative drive in many of us"..$^{18}$ Ready to Fly: The Story of New Zealand Rock Music covers much of the same ground as the Stranded in Paradise volumes but is notably more concerned with creating a sense of New Zealand music as unique, special and specific. Eggleton argues that:

The beginning of rock and roll in this country was undoubtedly derivative, imitative and generic, but it also had some recognizable local features - echoes of our sea shanty and bush ballad traditions, along with unmistakable Polynesian harmonies and rhythms. ${ }^{19}$ 


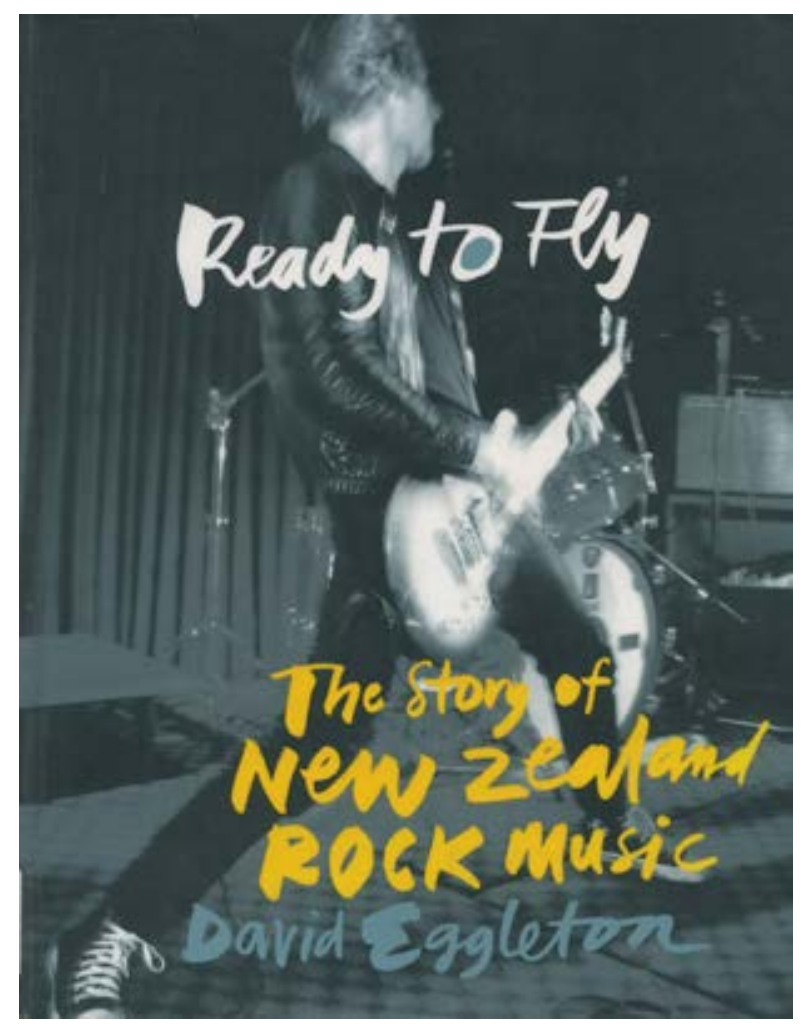

Further to this, Eggleton claims that New Zealand music is essential to understanding what it is to be a 'New Zealander', in that "our sense of national identity began to register in this new cultural form ${ }^{\prime 20}$ and that New Zealand music would be recognizable anywhere in the world as it:

Will inevitably have something of the raw and the strident, the gothic and the dark, the lilt and the breeziness of Noisyland, deep in the Pacific of bass. ${ }^{21}$

This is quite a remarkable claim to make, considering Eggleton's other claims about the universality of 'rock' music made in Ready to Fly. He is particular in pointing out that New Zealand musicians were following their counterparts worldwide in reconstructing rock music as "the raging primal potency of rock and roll is always being reinvented and restated in ever adjusting formats", 22 and that "rock music endures through constant revisionism". ${ }^{23}$ Eggleton somewhat downplays the influence of government intervention in popular music via New Zealand on Air from 1989, preferring for the most part to lump its work in with "the rebranding of New Zealand's economic identity". ${ }^{24}$ This is a flaw in Ready to Fly, as there are strong arguments to make about the privileging of the type of New Zealand music that is selected for funding, promotion and air play that has heavily influenced what is considered 'New Zealand' music. ${ }^{25}$ There is a missed opportunity here to explore the influence of key tastemakers in government departments, the media and in the New Zealand music industry over what is considered 'popular' and by extension, economically viable music worthy of support.

$$
\text { Ready to Fly is notably nationalistic and unashamedly }
$$

uncritical - as it is aimed at a broad popular market, perhaps to cash in on the end of the 'cultural cringe' posited by Neill (2005) and Dix (2005) earlier. However, Ready to Fly does serve to again demonstrate a new eagerness to discuss the construction of new narratives about what New Zealand music means to New Zealanders and about the power of the popular music to influence not just the media, audiences and the music industry, but also governments and policy makers.

During this period, Gareth Shute produced two comprehensive studies of music in New Zealand, one genre specific, Hip Hop Music in Aotearoa (2004), and a broader work NZ Rock 1987-2007 (2008).

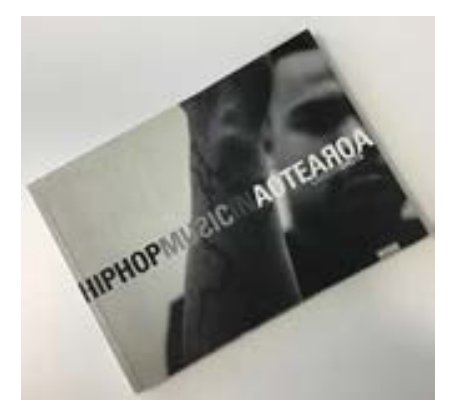

Hip Hop Music in Aoteroa, 2004

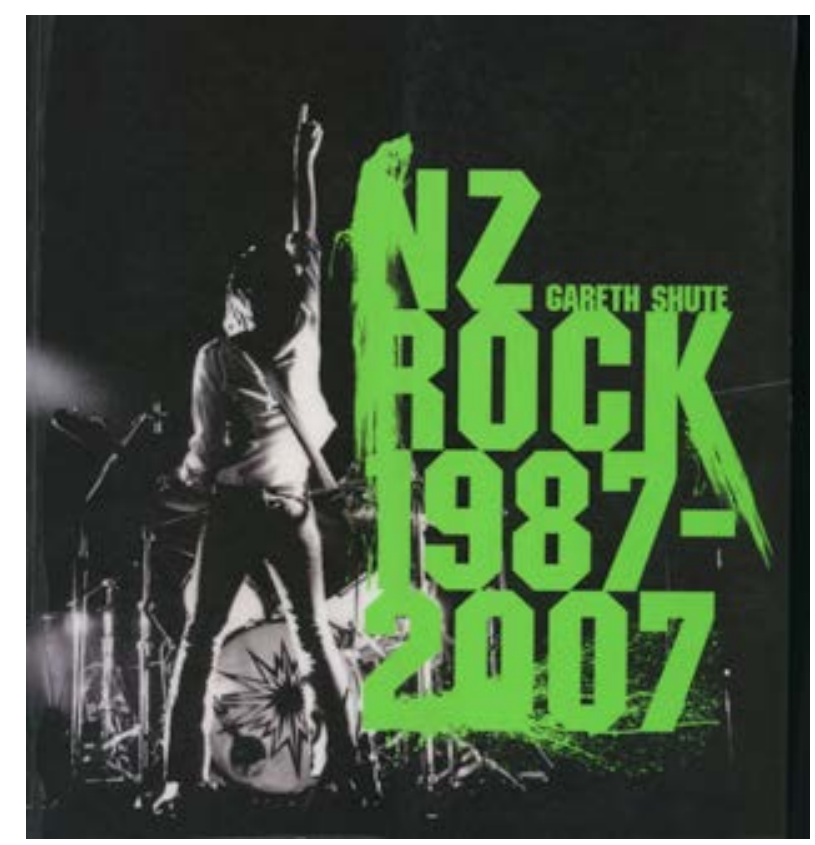

Hip Hop Music in Aoteroa, 2004 
Shute is both a musician and a writer and manages to capture New Zealand music scenes from the perspective of a practitioner, fan and a popular historian. Hip Hop Music in Aotearoa is a detailed exploration of the roots of the form in New Zealand, tracing and connecting a lineage from Māori waiata (song) and Pacific music styles through international black music movements such as reggae and the early New York developments of Hip Hop as a style that also contained social and political critiques that resonated with disaffected and marginalized Māori and Pacific Island youth in New Zealand. ${ }^{26}$ Hip Hop Music in Aotearoa is important in that it opens a narrative previously sidelined by the 'bigger' story of New Zealand music as an amorphous and overarching system, with little variation or internal dissent apparent. Shute instead argued that the diversion of talented Māori and other Polynesian musicians away from the overwhelmingly 'white' culture of the New Zealand music and broadcasting establishment was social, political, economic and ultimately redemptive for those involved, who are quoted extensively throughout the work. Again, Shute mixed the international with the local, arguing for a form of hybrid Hip Hop culture developing in New Zealand that was both easily recognizable to outsiders, but also unique to New Zealand as a South Pacific nation.

Shute's 2008 book takes a broader view of a period in New Zealand music that was driven by a change in direction brought about by the advent of New Zealand on Air. NZ Rock 1987-2007 is a comprehensive look at the major success stories of the era, with some fine grain detail added by exploring lesser known artists and their struggles to either fit into the economic structures of the New Zealand music industry or to survive and thrive outside of it. Here too there is considerable detail added by the artists themselves, as they remember those struggles and triumphs, but also the very real change in the status, economics and recognition of New Zealand music as government policies began to influence the music industry, the media and audiences in New Zealand, and abroad. Shute argues that political pressure over introducing New Zealand music quotas, a commercialfree, publicly funded Youth Radio Network and growing confidence among artists served to push policy makers into developing a more comprehensive strategy for music that also included the development of associated industries such as professional music management, recording and marketing. This worked alongside the New Zealand on Air funding system to energize the music industry and the broadcasting industry into a remarkably cooperative period that was mutually beneficial over the 20 -year period described. ${ }^{27}$ Shute also notes that "all

of this goodwill would have been nothing without the songs" and pays particular attention to successful artists who were 'groomed' carefully by both government agencies and record companies working in close partnership..$^{28}$ Ultimately, NZ Rock 1987-2007 is, like its predecessors mentioned here, celebratory and largely uncritical. It is however a fascinating documentation of a quite remarkable period of growth, success and development in New Zealand popular culture that shows that deliberate, carefully planned and orchestrated government intervention can make a significant difference to a cultural sector.

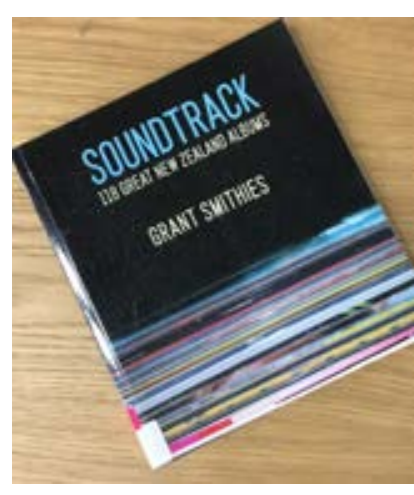

Soundtrack: 118 Great New Zealand Albums, 2007

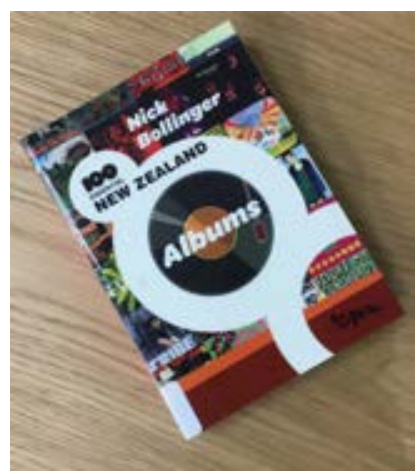

100 Essential New Zealand Albums, 2009

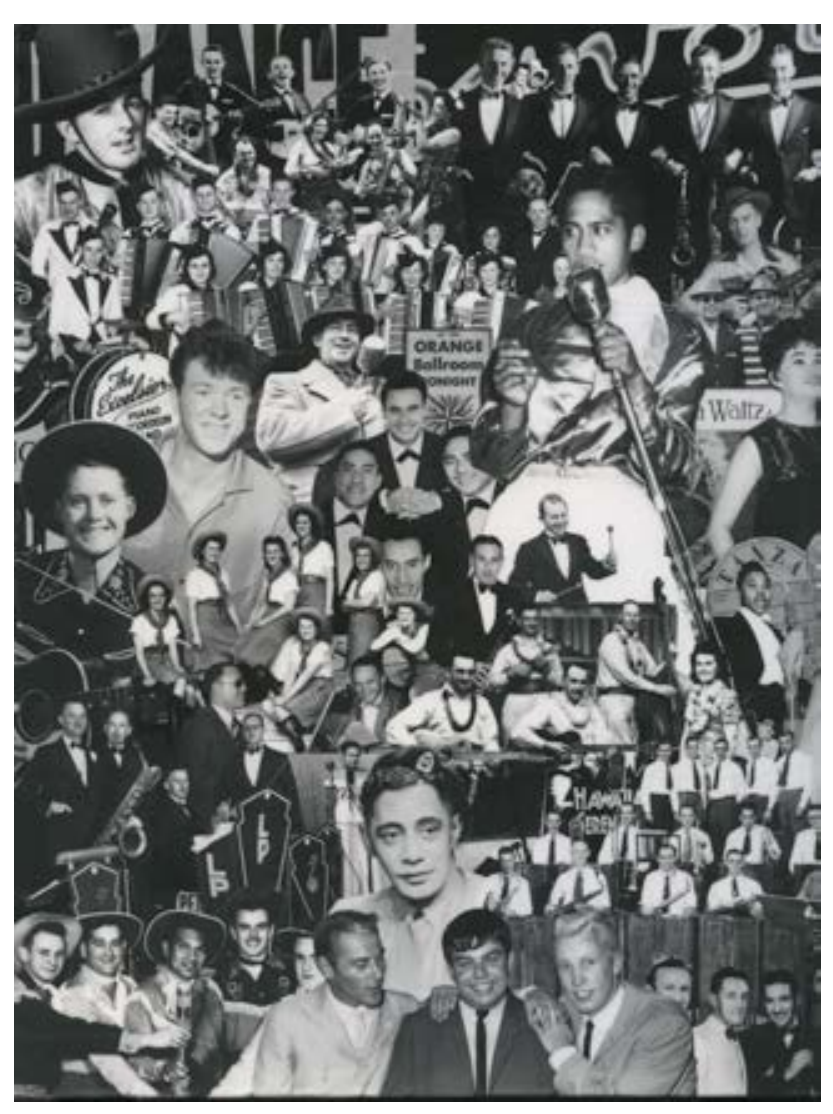

Blue Smoke, 2010 


\section{CRITICS AND THE 'BEST OFS'}

Another notable trend in writing on New Zealand music of the time is 'best of' compilations of favourite albums, produced by well-known New Zealand music critics. The first of these is Soundtrack: 118 Great New Zealand Albums by Grant Smithies (2007), an established critic for Fairfax Media (NZ) publications at the time. Smithies claimed some disdain for the format, stating "I've never been a fan of those facile 'Best New Zealand Single Ever' lists that crop up from time to time" as "culture is not a horse race" and therefore somewhat subverts the typical 'best of' structure. ${ }^{29}$ Soundtrack begins with the premise that it is "crammed with blind prejudices, foggy memories, rash declarations, unsubstantiated assertions and, quite probably, lies". ${ }^{30}$ That said, it also offers potted histories of all 118 albums covered, partly to "address a historical injustice" Smithies sees in the hyping of commercially success, rather than unique, emotive and generally more artfully conceived albums made in New Zealand. ${ }^{31}$ Part of what Soundtrack is about is Smithies' ongoing discussion in his reviews and columns about what music means to a society, and how to write about it. Smithies discusses the complex role of musicians and music through examining their artefacts and the effect of those on society. Interestingly, he lets others take over the narrative from time to time, to reinforce this complexity as musicians, other critics and sundry others from a cricket historian to a film director discuss their affinity with certain albums, artists and scenes. Soundtrack may be "proudly subjective ... and by no means exhaustive or definitive", but it is also intelligent, thoughtfu and ultimately, revealingly complex. ${ }^{32}$ Significantly, Smithies makes no claims for a unique New Zealand music, or for an isolated music industry at the end of the world. He does however treat music as of a place, claiming:

There are extra layers of meaning to be gleaned from art made somewhere just up the road, by someone who has grown up with a similar bunch of cultural references to yourself, eating similar tucker, moving through the same landscapes, watching the same crappy ads on the telly. ${ }^{33}$

In many ways Soundtrack goes far beyond the earlier trend of writing detailed and celebratory histories of New Zealand music and is more critical - teasing out the influences of place, policy and power on music made in New Zealand.
Nick Bollinger managed to follow the format in 100 Essential NZ Albums (2009). Bollinger was a long-standing music critic for the public radio broadcaster, Radio New Zealand and the culture and current affairs weekly publication The New Zealand Listener. Bollinger is also a musician and producer and brings those perspectives to his popular critiques. 100 Essential NZ Albums is mainly concerned with popular New Zealand music that has had a measure of commercial and/or critical success and does not delve as deeply or widely as Soundtrack does. Bollinger claims digital technology such as easy home recording, drum machines and 'auto-tune' systems means that finding more recent music that is truly special is getting harder. Arguing that "more than ever, it has become necessary to seek out and celebrate originals, the singers and bands who come up with something unpredictable and beautiful", Bollinger made no claims for a unique New Zealand music, but chooses the 100 albums by the criteria of them being made by New Zealanders, anywhere in the world and by them "speaking to me today". ${ }^{34}$ Bollinger admitted that "some undoubted milestones have dated so badly" they were left out, claiming that "that is the nature of most pop - it is built to last only until the next thing comes along". ${ }^{35}$ What 100 Essential NZ Albums offers is a critique of significant moments in music made by New Zealanders, spanning 60 years, and still resonating today in discussions of what is unique or special about popular music made by New Zealanders. Bollinger generally avoids politics and economics in his critique, focusing instead on the musicality, unique sensibilities and ongoing influence of the albums chosen. To this end, 100 Essential NZ Albums can be seen as part of the construction of myths around the 'New Zealand-ness' of music made by New Zealanders, more so than Smithies but not to the extent of others mentioned here. This is important as part of the wider narrative about the 'value' of New Zealand music and how that value is traded upon by artists, businesses and governments to create music, make money or to win votes.

Chris Bourke (2010) forefronts the influence and success of Māori music in an exhaustive study of a vibrant period in New Zealand's musical heritage in Blue Smoke, named after the first record to be completely made in New Zealand, from composition, to recording, to pressing, in 1949. Bourke mixes stories of the local songs, bands and record companies with the arrival of music from the United Kingdom at first, and increasingly the United States from 1918 onwards. Blue Smoke again shows the tendency of New Zealand musicians to view themselves as part of a wider culture of music as they borrowed liberally from 
overseas while adapting Māori musical forms such as waiata (song) to new instruments, recording techniques and performance styles from international popular music culture. These bands then took this adaptation with them on tours to Australia, the Pacific Islands, Europe and the United States, both mimicking and reinventing a common popular music culture that transcended national borders. Bourke argues that "music, like a virus, respects no borders" and combined with the rapid technological change of the 20th century "popular music was a conspicuous example" of the disruption, innovation and crosspollination of international cultures interacting with national cultures. ${ }^{36}$ What is remarkable is the 'ordinariness' of transcribing, reconfiguring and borrowing musical styles in New Zealand - making it a place very geographically isolated, yet very much part of a trans-national Western musical culture.

\section{ATTEMPTING TO CONTEXTUALISE NEW ZEALAND MUSIC: VIEWS FROM THE ACADEMY}

While the eight books discussed here were efforts to place popular New Zealand music in 'mainstream' or 'accessible' formats and frames, this moment also created new interest from academics. This reinforces the significance of this period in publishing about New Zealand music and broadens the discussion of what it meant. Roy Shuker and Michael Pickering began to explore the relationship between popular music and cultural identity in New Zealand in 1994. Noticing "a series of high points", which included the publishing of Stranded in Paradise, a successful convention about New Zealand music and a significant increase in New Zealand songs in the charts among positive signals, Shuker and Pickering asked if the New Zealand music industry was "in good heart". ${ }^{37}$ They concluded that "the vital signs are in fact mixed"38 in that a general lack of support from the media, a lack of professional music management skills, underfunding of promotional campaigns, the focus of international record labels on developing only artists that could fit international markets, and a need for more government engagement in popular music as critical. Shuker and Pickering focused on the debate around imposing legal quotas on radio to play New Zealand music, and problematized the notion of what New Zealand music means, in terms of how it sounds, the lyrics, the commercial potential (or otherwise) of local music scenes, the influence of international labels on artists, the dominance of Anglo-American youth culture in a globalised world and the production techniques and standards used. They argued that the New Zealand music industry was a "useful example of the tensions that exist between the core and the periphery in the global music industry" 39 and that "questions of the relationship between popular music, local cultural identity, and the internationalisation of the music industry are strongly present in New Zealand". ${ }^{40}$

Shuker and Pickering go beyond arguments for cultural imperialism and essentialist notions that New Zealand musicians "embody and support a local cultural nationalism in their work". ${ }^{41}$ They argued that there is very little evidence for unique, culturally specific New Zealand music and that "what counts as popular music has been identified with a particular imported form, the result of the dominance of American radio formats, music videos, and production values", meaning that "local product is often qualitatively indistinct from its overseas counterparts", which would make arguments for a radio quota because of the value of supporting unique, binding and 'national' music that reflect New Zealand culture untenable..$^{42}$ Instead, Shuker and Pickering made an economic argument for airplay quotas, noting that New Zealand musicians were marginalised in their own country by international music and that the most successful had moved to larger markets overseas. The introduction of a quota would assumedly increase exposure and sales of New Zealand music, helping more artists to make a living off music in New Zealand. Ultimately, Shuker and Pickering were early exponents of interrogating the interplay of local/ international in New Zealand music in the global age and argued for a better mix of policies that would reflect this in terms of the economics of New Zealand music.

Shuker (2008) revisited the New Zealand popular music scene 14 years later to examine the impact on popular culture of the interventions of New Zealand on Air. Shuker noted "impressive growth" and that New Zealand's popular music industry had matured to the point that it was "poised to make a significant international impact". ${ }^{43}$ This he attributed to strong government support, the well thought out and incremental interventions of New Zealand on Air, and the close and cooperative relationships that had developed between government agencies, the music industry and the broadcasting industries. Shuker also describes the emergence of two significant musical movements that had flourished with targeted government support or by building strong local audiences, an independent business plan and by utilising 
local and global networks to create touring and sales opportunities. 'Indie' and 'garage rock' and 'New Zealand urban Polynesian sounds' are interrogated as demonstrating the complex interplay between local and global cultures. Shuker claimed that indie and garage rock artists from New Zealand, while interesting, popular and born of "long honourable tradition in New Zealand", have nothing "distinctively local about their music", even though it was eligible for New Zealand on Air support. ${ }^{44}$ The growing popularity locally and internationally of a New Zealand-based, pan-Polynesian sound, significantly influenced by Bob Marley and other reggae artists, as well as Polynesian and Māori spirituality - which privilege a sense of connectedness to the land, sea, place and one's ancestors - are characterised by Shuker as "local inflections of imported musical styles", which strongly resonated with young Māori and Polynesian music consumers in the most Polynesian place in the world. ${ }^{45}$ Shuker reasserted that popular music made in New Zealand reflected the "transformation of the global circulation of cultural forms", creating "new lines of influence and solidarity, which are not bounded by geographically defined cultures". ${ }^{46}$ Shuker notes that the "local and the foreign... are not binary categories but exist in complex interrelationship' which makes it makes it necessary to distinguish between local music and locally made music. ${ }^{47}$ Further, Shuker argued that while the government still used the rhetoric of culture and local identity to justify spending on locally made popular music, it's "pragmatic concern" was the "economic value of the industry", which displaced notions of the value of national musical culture. ${ }^{48}$

Tony Mitchell (2011) offered 'place-based' and 'locative approaches' to understanding music in New Zealand, that are both genre-based but also significantly concerned with the places such as towns and cities that music is made in. ${ }^{49}$ Mitchell cited one such study in the biggest New Zealand city - Auckland - exploring the changing dynamics of its musical culture through periods, venues and demographic upheavals that shape a new 'multicultural' music climate, while more traditional forms of rock and other popular music continue to emerge from the diverse urban environment of a city increasingly influenced by peoples of the Southern Pacific, but also connected to the major global music movements of the time. Mitchell's study of Auckland music revealed the politics of musical identity through songs made in a young city geographically removed from the major centres of Western music but collecting international cultural moments and mixing them with the landscape, places and peoples in what he describes as an "Auckland poetics of place". ${ }^{50}$
Michael Scott (2008) added complexity to this focus on place by exploring notions of the 'network state' in relation to "a period of unprecedented audibility and visibility' for New Zealand music". ${ }^{51}$ Arguing that the 'pop renaissance' was a result of "partnership between the state, via NZOA, and commercial radio" which delivered appropriate product to commercial radio to fulfil its own 'voluntary quota', Scott demonstrated that New Zealand on Air had invested in particular artists and genres as a "calculated state investment conditioned by the economic and cultural logics of the commercial broadcasting field", which effectively overturned the freedom of artists to 'create' in favour of conforming to radio's format conventions. ${ }^{52}$ Scott called radio "a central institution in New Zealand's pop renaissance" that "plays a pivotal role in breaking new acts and the success of new ones", noting that the head of music for New Zealand on Air was unequivocal about this in stating "we are not actually in the music business, we are in the airplay business". ${ }^{33}$ While there was rhetoric from state agencies about national culture and identity, the networked state now chiefly linked "cultural and economic aspirations" as New Zealand on Air "developed an entrepreneurial role" that facilitated creating highly commercial radio-friendly music. Scott argued that "the success of the programme is based upon state agents developing an institutional isomorphism with existing music industry practices" that joined up New Zealand-made, commercially focused pop music with New Zealand commercial radio. ${ }^{54}$ Scott, in conjunction with David Craig (2012), then took the active involvement of the New Zealand government further by interrogating the 'promotional state'. Scott and Craig, in response to Simon Frith and Neil Cloonan's call to "analyse more closely the ideologies of governance that undergird music policy", ${ }^{55}$ question the legacy of neo-liberalism and attempts by New Zealand's fifth Labour government to distance itself from the upheaval and turmoil of the neo-liberal 80 s and 90 s in New Zealand by becoming more interventionist in the cultural sector.

Acknowledging the complex interactions and the "plurality of domains and fields" of governance as it is "constituted through a complex assemblage of relations comprising institutions, apparatuses and organisations, and state and non-state actors each with specific know-hows", ${ }^{56}$ Scott and Craig characterise Labour's interventions in popular music as characteristic of the promotional state "which designs policies and programmes to support the audibility and visibility of domestic sounds" ${ }^{57}$ Further to this are attempts by the state to weave popular music through "heterogeneous economic, social and 
cultural goals" along with its susceptibility to "incorporation into social welfare policies and programmes" as music is located primarily in youth culture, problematizes the place of popular music as representative of national culture. ${ }^{58}$

The election of the fifth Labour government on a platform of healing social rifts that emerged during the neo-liberal experiment of the $80 \mathrm{~s}$ and $90 \mathrm{~s}^{59}$ is important to the new visibility of New Zealand music in print and elsewhere during this period. Local popular music was to play a prominent part in the 'healing' and 'state enablement of the market' was seen as part of a new era of 'after neo-liberalism' intervention in the economic, cultural and social spheres of $\mathrm{New}$ Zealander's lives. ${ }^{60}$ Scott and Craig included the theoretical insights of New Institutional Economics (NIE) in their examination of this new interventionism, which analysed interactions between firms, governments, policies, economic interactions and "the market dimensionalities of public and private institutions" in order to 'reduce transaction costs' and improve efficiencies by deliberate intervention, rather than relying on the neo-classical laissez-faire economic approach with its lack of regard for the people involved in transactions, the social contexts they operate in, the changing behaviours of actors, institutional configurations and the ongoing development of institutions. ${ }^{61}$ This resonates with the experience of New Zealand on Air intervening in the popular music market and the broadcast medic on behalf of the state in that "the high degree of social connectivity and conviviality needed to create commercially successful artists" was beyond neo-liberal positions of market-centric production. ${ }^{62}$

The place of national culture in this reconfiguration is unclear. The 'promotional state' privileged commercially viable forms of music culture in New Zealand, meaning its efforts to create institutions, policies and opportunities to monetise New Zealand music reinforced the rigidity of commercial radio format requirements. While it can be argued that state intervention via the construct of 'after neo-liberalism' had created a vastly different music system in New Zealand that launched and sustained many successful careers, there is an argument to be made for it also creating 'churn' in artists, songs, styles and fads as the reorientation of popular music has seen "new acts endlessly shuffling through" funding and programmes that are designed to reach government economic goals. ${ }^{63}$ This system allows no room to long-term artistic endeavour, to slow growth and to notions of music as of a place and reflective of that. Instead, it facilitates conduits and connections between the local and international music industry, commercial broadcasting and particular artists and government agencies in order to create new markets for musical 'products', with the added benefits of supposed "opportunity, empowerment social inclusion and new institutional thought". ${ }^{64}$

Scott and Craig ultimately argued that the 'promotional state' analysis could go beyond the supportive subsidy and quoto interpretations, narratives of interventions in the market or discursive analysis of policy formation, to consider more closely how "ideologies of governance can affect conduct on the ground". ${ }^{65}$ To that end, the 'promotional state' in New Zealand is embodied in New Zealand on Air and its contention that it is 'in the airplay business', and not the business of creating culture. Scott and Craig argue that the promotional state as created by the fifth Labour government showed "how the ideological legacy of neo-liberalism and its emphasis on markets, competition and the gain spirit continued to influence Labour's 'after neo-liberal' polices" that supported New Zealand music. Concerns about national culture were in effect subsumed by market-driven realities and economic thinking, albeit in a different, friendlier guise. ${ }^{60}$

The short, but notable period of enthusiasm around New Zealand music that produced a relatively significant amount of popular literature about it was important in that it reflected a surge in national pride around music made in New Zealand. Ultimately, that pride and activity was to be subsumed by the hard contingencies of competition with a global music market that was played out in government policy settings that were designed to bring that music to the market, rather than reinforce notions of a national music culture that was worthwhile in and of itself. 


\section{REFERENCES}

Ashley, Sheran, and Brian Staff. For the Record: A History of the Recording Industry in New Zealand. Auckland: David Bateman Ltd. 2002

Biddle, lan and Vanessa Knights. "Introduction", in lan Biddle and Vanessa Knights (eds.), Music, National Identity and the Politics of Location. Aldershot: Ashgate Publishing, 2007: 1-15.

Bollinger, Nick. 100 Essential NZ Albums. Wellington: Awa Press, 2009

Bourke, Chris. Blue Smoke: The Lost Dawn of New Zealand Popular Music 1918-1964. Auckland: Auckland University Press, 2010

Shute, Gareth. Hip Hop Music in Aotearoa. Auckland: Raupo Publishing, 2004

Shute, Gareth. NZ Rock 1987-2007. Auckland: Random House, 2008.

Dix, John. Stranded in Paradise: New Zealand Rock and Roll 1955 to the Modern Era. Auckland: Penguin, 2005.

Dubber, Andrew. "Tutira Mai Nga Iwi (Line Up Together, People): Constructing New Zealand Identity Through Commercial Radio," The Radio Journal - International Studies in Broadcast and Audio Media 5, no. 1 (2007): $19-34$

Eggleton, David. Ready to Fly: The Story of New Zealand Rock Music. Nelson: Craig Potton Publishing, 2003.

Hendy, David. "Radio in the global age". New Media and Society, 3 No.3 (2000): 381-385.

Keam, Glenda, and Tony Mitchell. Home, Land and Sea: Situating Music in Aotearoa New Zealand. Auckland: Pearson, 2001

Mitchell, Tony (2011). "Songlines and Timelines through Auckland: Music in the 'Queen City' in Glenda Keam, and Tony Mitchell (eds.). Home, Land and Sea: Situating Music in Aotearoa New Zealand. Auckland: Pearson, 2011: 116-132.
Regev, Motti. "Rock Aesthetics and Musics of the World," in Frith, Simon. (ed.). Popular Music: Critical Concepts in Media and Cultural Studies. London: Routledge, 1997: 412-429.

Neill, Karen. "Getting Radio Friendly: The Rise of New Zealand Music on Commercial Radio," In Karen Neill, Karen. \& Morris W. Shanahan (eds.). The Great New Zealand Radio Experiment. Victoria: Thomson Dunmore Press, 2005: 17-46.

Scott, Michael. “The Networked State: New Zealand on Air and New Zealand's Pop Renaissance," Popular Music 27, no. 2 (2008) 299-305.

Scott, Michael and David Graig. "The Promotional State 'After Neo-Liberalism': Ideologies of Governance and New Zealand's Pop Renaissance," Popular Music 31, no. 1 (2012): $143-163$.

Shuker, Roy and Michael Pickering. "Kiwi Rock: Popular Music and Cultural Identity in New Zealand," Popular Music 13 no. 3, (1994): 261 278.

Shuker, Roy. "New Zealand Popular Music, Government Policy, and Cultural Identity," Popular Music 27 no. 2, (2008): 271-287.

Shute, Gareth. Hip Hop Music in Aotearoa. Wellington: Raupo Publishing, 2004.

Shute, Gareth. NZ Rock 1987-2007. Auckland: Random House, 2008

Smithies, Grant. Soundtrack: 118 Great New Zealand Albums. Nelson: Craig Potton Publishing, 2007.

\section{END NOTES}

1 Motti Regev, "Rock Aesthetics and Musics of the World," in Simon Frith (ed.). Popular Music: Critical Concepts in Media and Cultural Studies. (London: Routledge, 1997), p. 426

2 lbid, pp.426-427.

3 Ibid, p.427.

4 David Hendy, "Radio in the global age". New Media and Society, 3 No.3 (2000): pp 64-5.

5 Biddle, lan and Vanessa Knights. "Introduction", in lan Biddle and Vanessa Knights (eds.), Music, National Identity and the Politics of Location. (Aldershot: Ashgate Publishing, 2007), p.2.

6 Ibid, p.3.

7 Ibid, p.12

8 lbid.

9 lbid, p.14.

10 Ibid.

11 John Dix. Stranded in Paradise, (Auckland: Penguin, 2005), p.10.

12 lbid.

13 lbid, p.290

14 Ibid, p.288

15 Sheran Ashley and Brian Staff. For the Record: A History of the Recording Industry in New Zealand. (Auckland: David Bateman 2002), p. 150.

16 Bourke, Chris. Blue Smoke: The Lost Dawn of New Zealand Popular Music 1918-1964. (Auckland: Auckland University Press, 2010), 1. p.1.

17 Martin Phillips, Foreword (p. 7) in David Eggleton. Ready to Fly: The Story of New Zealand Rock Music. Nelson: Craig Potto Publishing, 2003).

18 Ibid.

19 David Eggleton. Ready to Fly: The Story of New Zealand Rock Music. Nelson: Craig Potton Publishing, 2003), p.190.

20 Ibid.

21 Ibid, p.191.

22 Ibid, p.176.

23 Ibid, p.191.

24 lbid.

25 Andrew Dubber. "Tutira Mai Nga Iwi (Line Up Together, People): Constructing New Zealand Identity Through Commercial Radio, The Radio Journal - International Studies in Broadcast and Audio Media 5, No.1 (2007).

26 Gareth Shute, Hip Hop Music in Aotearoo. Wellington: Raupo Publishing, 2004

27 Gareth Shute, NZ Rock 1987-2007( Auckland:Random House, 2008), pp. 184-185.
28 lbid., p. 185.

29 Grant Smithies, Soundtrack: 118 Great New Zealand Albums (Nelson: Craig Potton, 2007) p. 11.

Ibid, p.7.

31 Ibid. p. 8

32 Ibid.

33 lbid, p.7.

34 Nick Bollinger, 100 Essential Albums(Wellington: Awa Press, 2009), p.xi.

35 Ibid. p. xii.

36 Chris Bourke, Blue Smoke: The Lost Dawn of New Zealand Popular Music 1918-1964 (Auckland: Auckland University Press, 2010), p. 4

37 Roy Shuker and Michael Pickering. "Kiwi Rock: Popular Music and Cultural Identity in New Zealand," Popular Music 13, No.3, (1994): 261.

38 lbid.

$39 \mathrm{Ibid}$, p. 262

40 ibid. p. 275.

42 lbid, pp. 275-6.

43 Shuker, Roy. "New Zealand Popular Music, Government Policy, and Cultural Identity," Popular Music 27 No.2, (2008): 271.

44 Ibid, pp.280-1.

$45 \mathrm{lbid}$, p. 282.

46 Ibid.

49 Glenda Keam and Tony Mitchell, Home, Land and Sea: Situating Music in Aotearoa New Zealand(Auckland: Pearson, 2001): $x$-xi.

50 lbid, p.130.

51 Michael Scott, "The Networked State: New Zealand on Air and New Zealand on Air and New Zealand's Pop Renaissance," Popular Music 27, No.2 (2008): 299.

$52 \mathrm{lbid}$, p. 304

53 Ibid, p. 300

$54 \mathrm{lbid}$, p. 299.

55 Michael Scott and David Graig. "The Promotional State 'After Neo-Liberalism': Ideologies of Governance and New Zealand's Pop Renaissance, Popular Music 31, No.1 (2012): 143.

56 Ibid, p. 145

57 Ibid, p. 146.

58 Ibid, p. 147

59 lbid, p. 150

60 Ibid, p. 152 